\title{
Breeding seabirds in the British Virgin Islands
}

\author{
Andrew McGowan ${ }^{1, *}$, Annette C. Broderick ${ }^{1}$, Shannon Gore ${ }^{2}$, Geoff Hilton ${ }^{3}$, \\ Nancy K. Woodfield ${ }^{4}$, Brendan J. Godley ${ }^{1}$ \\ ${ }^{1}$ Centre for Ecology and Conservation, University of Exeter, Cornwall Campus, Tremough, Penryn TR10 9EZ, UK \\ ${ }^{2}$ BVI Conservation and Fisheries Department, PO Box 3323, Road Town, Tortola, British Virgin Islands \\ ${ }^{3}$ Royal Society for the Protection of Birds, The Lodge, Sandy SG19 2DL, UK \\ ${ }^{4}$ BVI National Parks Trust, PO Box 860, Road Town, Tortola, British Virgin Islands
}

\begin{abstract}
Caribbean seabirds are subject to numerous threats, and population levels are thought to be at a fraction of historical levels. Despite being a well-known taxonomic group there is still a paucity of data for most seabird species on many of the Caribbean islands. We carried out detailed surveys of the seabird breeding populations in the British Virgin Islands (BVI) during the breeding seasons of 2004 and 2005. We surveyed 42 different islands and cays over the $2 \mathrm{yr}$ with 60 and $63 \%$ of these having at least one breeding seabird species in 2004 and 2005, respectively. A total of 15 species of breeding seabird was recorded, one of which, the gull-billed tern Sterna nilotica, was previously thought to have been extirpated. Two species, roseate tern Sterna dougallii and magnificent frigatebird Fregata magnificens, had globally significant colonies in the BVI and a further 8 species had a regionally significant population in the BVI. We discuss our findings within a global and regional conservation context and provide recommendations for ensuring the continued existence of BVI seabird populations.
\end{abstract}

KEY WORDS: Birds $\cdot$ Caribbean $\cdot$ Conservation $\cdot$ Monitoring $\cdot$ British Virgin Islands Resale or republication not permitted without written consent of the publisher

\section{INTRODUCTION}

The Caribbean islands are among the most biologically diverse regions on earth and support large numbers of endemic plants and animals, considering their relatively small land area (Myers et al. 2000). In the Caribbean region there are over 600 species of bird (Conservation International 2005), including 22 species of seabird, 2 of which, the Jamaica petrel Pterdroma caribbea and the black-capped petrel Pterdroma hasitata, are endemic (Schreiber \& Lee 2000). Despite their conspicuousness and relatively charismatic status, there are still many data deficiencies for the majority of seabird populations in the Caribbean islands. Populations in this region are thought to be at a fraction of their historical levels. They are subject to widespread and numerous threats, namely habitat loss, human disturbance and consumption of eggs, and the impact of introduced vertebrate predators, especially rats and cats (Schreiber \& Lee 2000).
Biogeographically, the British Virgin Islands (BVI) form part of the Puerto Rican bank, along with Puerto Rico and the US Virgin islands (excluding St. Croix) (Fig. 1). The Puerto Rican bank is one of the 6 primary endemic bird areas in the Caribbean and is a priority area for conservation (BirdLife International 2003). It is thought that historically, 17 species of seabirds bred in the BVI, whereas the most recent reports suggest that only 14 species currently breed, as masked booby Sula dactylatra, gull-billed tern Sterna nilotica and royal tern Sterna maxima have been extirpated (Schreiber \& Lee 2000). For most of the surviving 14 species there is a general paucity of monitoring data, which renders the prioritisation and assessment of trends of seabirds in the BVI difficult (Schreiber \& Lee 2000).

This lack of baseline information for seabirds in the BVI is a fundamental barrier to the construction of management plans and implementation of any conservation actions that may be required for the preservation of their nesting and foraging habitats. Here, 


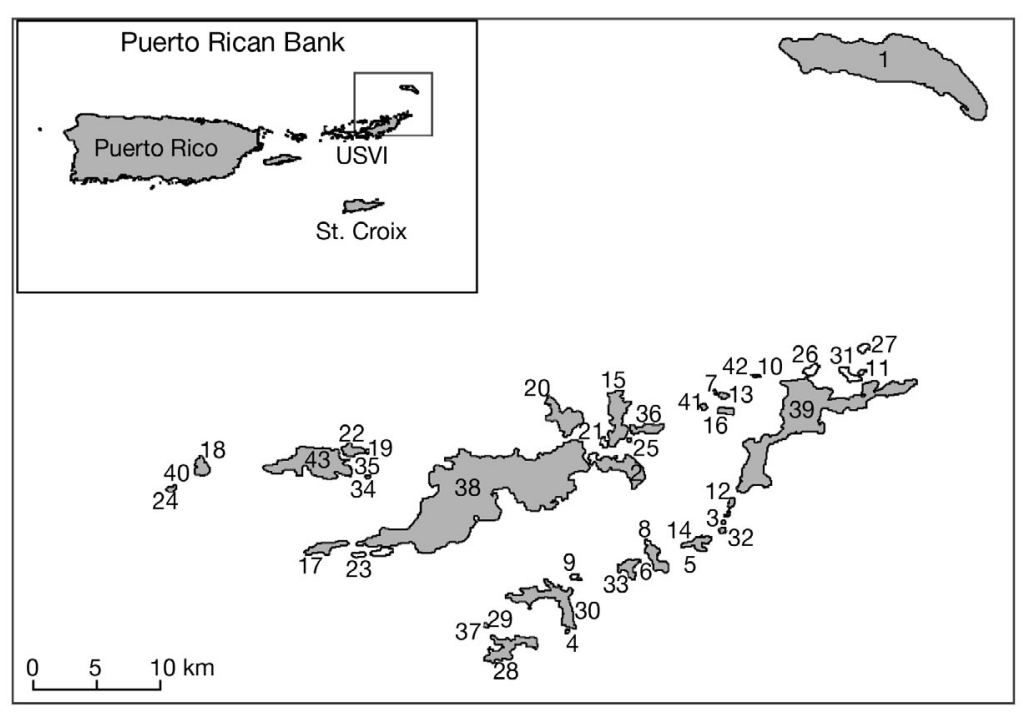

Fig. 1. British Virgin Islands (BVI). Inset shows location within the Puerto Rican bank. See Table 1 for a full list of individual island names

from a boat due to inaccessibility. Each island was slowly circumnavigated and a direct count of the number of each species of seabird present was recorded. Wherever possible, islands were groundtruthed on foot, and direct counts of active nests were made. In most cases where ground-truthing took place, a combination of direct counts and boat observations were used to estimate breeding numbers. As birds were not marked, we divided the archipelago up into discrete geographical units and surveyed islands that were in close proximity to one another on the same day, in order to reduce the potential problem of double counting.

Data on the estimated number of breeding seabird pairs in the Caribbean were taken from Schreiber \& Lee (2000). Global estimates of the number of breeding pairs were taken from the published literature

we present the most up-to-date information currently available on the breeding seabird populations in the BVI and discuss them within both a regional and global conservation context. In addition, we make recommendations for improvements to the current legislation and suggest the implementation of a territorywide monitoring scheme.

\section{MATERIALS AND METHODS}

Our original intention was to survey all 43 islands and cays in the BVI archipelago during each of the $2 \mathrm{yr}$ of this study (2004 and 2005), but this was not possible due to logistical constraints and inclement weather. We thus surveyed a total of 42 different islands and cays; 25 in 2004 and 40 in 2005 (Fig. 1, Table 1), 23 of which were surveyed in both years (Table 1). Surveys were typically carried out during May. Exceptions were Great Tobago (surveyed in February 2004 and May 2005) and Anegada (surveyed in May and July in both years). The decision to carry out the bulk of surveying in May was based on the phenological information available (Schreiber \& Lee 2000). This enabled maximum detection of tropicbird, gull and tern nesting (breeding May to August) in addition to other seabird species (breeding October to May).

Surveys were carried out between 08:00 and 18:00 h. Excluding Anegada, a total of 3 and $5 \mathrm{~d}$ were spent conducting surveys across the entire archipelago in 2004 and 2005, respectively. An additional 6 d were spent surveying Anegada for seabird colonies in each survey year (total $12 \mathrm{~d}$ ). Potential nesting sites on all islands, with the exception of Anegada, were observed on the number of estimated individuals (del Hoyo et al. 1992, del Hoyo et al. 1994, Rose \& Scott 1997, Schreiber \& Lee 2000) and halving this value. Species names and classification were used following those in Raffaele (1989).

\section{RESULTS}

In total, 42 different islands and cays were surveyed over the 2 yr study period (Table 1); $60 \%$ in 2004 and $95 \%$ in 2005 . The majority of islands were surveyed from a boat in both years, and 4 of 25 and 10 of 40 islands and cays were also ground-truthed on foot in 2004 and 2005, respectively (Table 1). Of the surveyed islands and cays, 60 and $63 \%$ had at least one species of breeding seabird in 2004 and 2005, respectively.

We recorded 15 species of seabird breeding in either 2004 or 2005, and 11 of these were recorded breeding in both the study years (Table 2). Bridled tern Sterna anaethetus was the most widely distributed species in the territory and was recorded on $32 \%$ of the islands surveyed in 2004 and $43 \%$ in 2005. Seven of the 15 breeding species were only recorded on a single island (Table 2). The number of breeding pairs in the majority of species was fairly consistent in both years, with the exception of the roseate tern $S$. dougalli (550 breeding pairs in 2004 and just 35 pairs in 2005, Table 2). Laughing gull Larus atricilla and magnificent frigatebird Fregata magnificens bred in the highest numbers, whilst less than 10 pairs of white-tailed tropicbird Phaethon lepturus, gull-billed tern, cayenne tern $S$. eurygnatha and common tern $S$. hirundo were recorded (Table 2). A single dead adult Audubon's 
Table 1. The 42 islands and cays of the British Virgin Islands (BVI) surveyed for breeding seabirds during 2004 and 2005. Location no.: geographical position on map in Fig. 1

\begin{tabular}{|c|c|c|c|}
\hline Island/Cay & Location no. & 2004 & 2005 \\
\hline Anegada & 1 & Yes $^{a}$ & Yes $^{a}$ \\
\hline Beef Island & 2 & - & Yes \\
\hline Broken Jerusalem & 3 & - & Yes $^{\mathrm{a}}$ \\
\hline Carrot Rock & 4 & Yes & Yes \\
\hline Carval Rock & 5 & Yes & Yes $^{\mathrm{a}}$ \\
\hline Cistern Rock & 6 & - & $\operatorname{Yes}^{\mathrm{a}}$ \\
\hline Cockroach Island & 7 & Yes & Yes $^{\mathrm{a}}$ \\
\hline Cooper Island & 8 & Yes & Yes \\
\hline Deadmans Chest & 9 & Yes & Yes \\
\hline East Seal Dog & 10 & Yes & Yes $^{\mathrm{a}}$ \\
\hline Eustatia & 11 & - & Yes \\
\hline Fallen Jerusalem & 12 & Yes $^{\mathrm{a}}$ & Yes $^{\mathrm{a}}$ \\
\hline George Dog & 13 & - & Yes \\
\hline Ginger Island & 14 & Yes & Yes \\
\hline Great Camanoe & 15 & Yes & Yes \\
\hline Great Dog & 16 & - & Yes \\
\hline Great Thatch & 17 & Yes & Yes \\
\hline Great Tobago & 18 & Yes $^{a}$ & Yes $^{\mathrm{a}}$ \\
\hline Green Cay & 19 & Yes & Yes \\
\hline Guana Island & 20 & Yes & Yes \\
\hline Little Camanoe & 21 & - & Yes \\
\hline Little Jost Van Dyke & 22 & Yes & - \\
\hline Little Thatch & 23 & Yes & - \\
\hline Little Tobago & 24 & - & Yes \\
\hline Marina Cay & 25 & - & Yes \\
\hline Mosquito Island & 26 & - & Yes \\
\hline Necker Island & 27 & - & Yes \\
\hline Norman Island & 28 & Yes & Yes \\
\hline Pelican Island & 29 & - & Yes \\
\hline Peter Island & 30 & Yes & Yes \\
\hline Prickly Pear & 31 & - & Yes \\
\hline Round Rock & 32 & - & Yes \\
\hline Salt Island & 33 & Yes & Yes \\
\hline Sandy Cay & 34 & Yes & Yes \\
\hline Sandy Spit & 35 & Yes & Yes \\
\hline Scrub Island & 36 & - & Yes \\
\hline The Indians & 37 & Yes & Yes \\
\hline Tortola & 38 & Yes & Yes \\
\hline Virqin Gorda & 39 & - & Yes \\
\hline Watsons Rock & 40 & - & $Y_{e s}^{a}$ \\
\hline West Dog & 41 & Yes $^{\mathrm{a}}$ & Yes $^{a}$ \\
\hline West Seal Dog & 42 & Yes & Yes \\
\hline Jost Van Dyke & 43 & - & - \\
\hline
\end{tabular}

shearwater Puffinus lherminieri was found on the island of Broken Jerusalem in 2005.

Contextualising our seabird data with regional and global census data allows us to assess the relative importance of the seabirds of the archipelago (Table 3). It can be seen that despite the relatively modest numbers of birds involved, 10 out of 15 species are regionally significant according to Birdlife International criteria of a $1 \%$ threshold limit for a significant population (BirdLife International 2003). Indeed, 4 of these 10 populations actually account for more than $5 \%$ of the regional population estimate. In a global context, one of the populations, the 2004 roseate tern colony on Cockroach Island, was globally significant, while another, the magnificent frigatebird colony on Great Tobago, approaches globally significant status.

Within a BVI context, in addition to any site that might host nesting by roseate terns (i.e. Cockroach Island, Cistern Rock, Necker Island, Virgin Gorda and historically Green Cay), the other islands of major importance are Great Tobago for its near globally significant magnificent frigatebird colony, and Anegada, as it is the only island in the territory that hosts 6 different breeding seabird species. Guana Island and Norman Island are also very important, as they are the only islands in the territory where brown pelicans Pelecanus occidentalis breed.

\section{DISCUSSION}

Despite logistical constraints, we have clearly established the regional and international importance of the seabirds of the BVI. The most notable of the assemblage was the globally significant population of roseate terns recorded breeding on Cockroach Island in 2004. However, between the 2004 and 2005 breeding seasons, the number of tern pairs in this territory fell from 550 to just 35 (Table 2). This species is well known for shifting breeding colony sites between years, due to disturbance or high levels of predation, and has been recorded breeding in large numbers on Green Cay (Saliva 2000). The drastic reduction in breeding pairs on Cockroach Island would appear to reflect this aspect of their behaviour, and it is probable that colonies in the US Virgin Islands and Puerto Rico are augmented with birds relocating from the BVI. However, such a drastic change in a globally important seabird colony warrants further investigation and emphasises the need for annual monitoring in the BVI.

The number of magnificent frigatebird pairs recorded in 2005 was less than for the previous year. We suspect this is more likely an artefact of survey timing, rather than a real change in population size, as many chicks would have fledged by the time the survey was conducted. The breeding adults at the frigatebird colony accounted for $0.53 \%$ of the estimated global population. Incorporating chicks and immature birds would almost certainly push the estimated population over the $1 \%$ threshold making irt a globally significant population.

Gull-billed terns have been reported as an extirpated breeding species in the BVI (Schreiber \& Lee 2000). However, we confirmed breeding on Anegada in 2005, with at least 4 pairs breeding in the remote salt 
Table 2. Numbers of breeding pairs of each of the seabird species recorded during surveys of the BVI archipelago in May 2004 and 2005. Island/Cay no.: see Table 1 \& Fig. 1

\begin{tabular}{|c|c|c|c|c|c|c|}
\hline \multirow[t]{2}{*}{ Species } & \multicolumn{2}{|c|}{ Breeding pairs (n) } & \multicolumn{2}{|c|}{ Island/Cay (n) } & \multicolumn{2}{|c|}{ Island/Cay no. } \\
\hline & 2004 & 2005 & 2004 & 2005 & 2004 & 2005 \\
\hline \multicolumn{7}{|l|}{ Audubon's shearwater } \\
\hline Puffinus lherminieri & - & $?$ & - & 1 & - & 3 \\
\hline \multicolumn{7}{|l|}{ Red-billed tropicbird } \\
\hline Phaethon aethereus & 10 & 10 & 3 & 3 & $4,5,18$ & $10,15,18$ \\
\hline \multicolumn{7}{|l|}{ White-tailed tropicbird } \\
\hline Phaethon lepturus & - & 5 & - & 2 & - & 27,39 \\
\hline \multicolumn{7}{|l|}{ Brown pelican } \\
\hline Pelecanus occidentalis & 100 & 65 & 1 & 2 & 28 & 20,28 \\
\hline \multicolumn{7}{|l|}{ Brown booby } \\
\hline Sula leucogaster & 145 & 87 & 3 & 2 & $5,14,18$ & 18,24 \\
\hline \multicolumn{7}{|l|}{ Magnificent frigatebird } \\
\hline Fregata magnificens & 800 & 500 & 1 & 1 & 18 & 18 \\
\hline \multicolumn{7}{|l|}{ Laughing gull } \\
\hline Larus atricilla & 505 & 523 & 8 & 11 & $1,9,10,12,20,41,42$ & $\begin{array}{c}1,4,6,7,9,10,12 \\
15,20,27,41\end{array}$ \\
\hline \multicolumn{7}{|l|}{ Gull-billed tern } \\
\hline Sterna nilotica & - & 4 & - & 1 & - & 1 \\
\hline \multicolumn{7}{|l|}{ Sandwich tern } \\
\hline Sterna sandvicensis & 20 & 25 & 1 & 1 & 1 & 1 \\
\hline \multicolumn{7}{|l|}{ Cayenne tern } \\
\hline Sterna eurygnatha & 2 & 2 & 1 & 1 & 1 & 1 \\
\hline \multicolumn{7}{|l|}{ Roseate tern } \\
\hline Sterna dougallii & 550 & 35 & 1 & 3 & 7 & $6,27,39$ \\
\hline \multicolumn{7}{|l|}{ Common tern } \\
\hline Sterna hirundo & 2 & - & 1 & - & 1 & - \\
\hline \multicolumn{7}{|l|}{ Least tern } \\
\hline Sterna antillarum & 60 & 55 & 1 & 1 & 1 & 1 \\
\hline \multicolumn{7}{|l|}{ Bridled tern } \\
\hline Sterna anaethetus & 88 & 140 & 8 & 17 & $4,5,10,12,14,37,41,42$ & $\begin{array}{c}3,4,5,7,10,12-14 \\
27,29,32,34,37,39-42\end{array}$ \\
\hline \multicolumn{7}{|l|}{ Brown noddy } \\
\hline Anous stolidus & 78 & 103 & 2 & 4 & 8,14 & $5,14,32,40$ \\
\hline
\end{tabular}

ponds, and it is highly likely that a small remnant population of gull-billed terns has been breeding there annually. The number of breeding pairs of all the other tern species, with the exception of roseate tern, was fairly consistent between years with bridled, common, sandwich Sterna sandvicensis, and least terns $S$. antillarum having regionally significant populations in the BVI (Tables 2 \& 3). A single pair of common terns was recorded during 2004 and this species is, in all likelihood, an opportunistic breeder in the BVI. However, due to the small numbers breeding regionally, just 1 or 2 pairs of common terns would account for $>1 \%$ of the beleaguered regional population. The only tern species recorded in the BVI that was not present in regionally important numbers was the cayenne tern $S$. eurygnatha (Table 3).

Brown pelican, laughing gull and brown booby Sula leucogaster numbers were fairly stable in both years despite the increased survey effort. Populations of each of these 3 breeding species exceed the $1 \%$ threshold, which emphasises the importance of the BVI for many different breeding seabird species in a Caribbean context.

Small numbers of both red-billed tropicbird Phaethon aethereus and white-tailed tropicbird P. lepturus were recorded during surveys. The white-tailed tropicbird is most likely to be an annual breeder in the BVI and was probably missed in 2004 due to the lower survey effort. Furthermore, numbers for both tropicbird species are probably grossly under-estimated (Lee \& Walso-McGehee 2000) and in reality probably exceed the $1 \%$ regional thresholds. It is likely that the limited time period spent surveying most islands biased our estimates in favour of those species that are more gregarious and remain close to their nesting colony. 
Table 3. Estimated number of breeding pairs of each seabird species occurring within the BVI, Caribbean and globally. ?: no data available

\begin{tabular}{|c|c|c|c|c|c|}
\hline Species & BVI & $\begin{array}{l}\text { Carib- } \\
\text { bean }^{\mathrm{a}}\end{array}$ & $\begin{array}{l}\% \text { Carib- } \\
\text { bean } \\
\text { population }\end{array}$ & $\begin{array}{l}\text { Global } \\
\text { pop- } \\
\text { ulation }\end{array}$ & $\begin{array}{c}\% \text { Global } \\
\text { pop- } \\
\text { ulation }\end{array}$ \\
\hline \multicolumn{6}{|l|}{ Audubon's shearwater } \\
\hline $\begin{array}{l}\text { Puffinus lherminieri } \\
\text { Red-billed tropicbird }\end{array}$ & $?$ & 4000 & $?$ & $4000^{\mathrm{a}}$ & $?$ \\
\hline Phaethon aethereus & 10 & 2150 & 0.47 & $10000^{\mathrm{b}}$ & 0.10 \\
\hline $\begin{array}{l}\text { White-tailed tropicbird } \\
\text { Phaethon lepturus }\end{array}$ & 5 & 3000 & 0.17 & $25000^{\mathrm{b}}$ & 0.02 \\
\hline $\begin{array}{l}\text { Brown pelican } \\
\text { Pelecanus occidentalis }\end{array}$ & 100 & 1500 & 6.67 & $125000^{\mathrm{C}}$ & 0.08 \\
\hline $\begin{array}{l}\text { Brown booby } \\
\text { Sula leucogaster }\end{array}$ & 145 & 6650 & 2.18 & $150000^{\mathrm{b}}$ & 0.10 \\
\hline $\begin{array}{l}\text { Magnificent frigatebird } \\
\text { Fregata magnificens }\end{array}$ & 800 & 4800 & 16.67 & $150000^{b}$ & 0.53 \\
\hline $\begin{array}{l}\text { Laughing gull } \\
\text { Larus atricilla } \\
\text { Gull-billed tern }\end{array}$ & 523 & 7500 & 6.97 & $400000^{\mathrm{d}}$ & 0.13 \\
\hline $\begin{array}{l}\text { Sterna nilotica } \\
\text { Sandwich tern }\end{array}$ & 4 & 300 & 1.33 & $55000^{\mathrm{d}}$ & 0.01 \\
\hline $\begin{array}{l}\text { Sterna sandvicensis } \\
\text { Cayenne tern }\end{array}$ & 25 & 2550 & 0.98 & $100000^{\mathrm{d}}$ & 0.03 \\
\hline $\begin{array}{l}\text { Sterna eurygnatha } \\
\text { Roseate tern }\end{array}$ & 2 & 5975 & 0.03 & 10975 & 0.02 \\
\hline $\begin{array}{l}\text { Sterna dougallii } \\
\text { Common tern }\end{array}$ & 550 & 5000 & 11.00 & $50000^{\mathrm{d}}$ & 1.10 \\
\hline $\begin{array}{l}\text { Sterna hirundo } \\
\text { Least tern }\end{array}$ & 2 & 75 & 2.67 & $375000^{\mathrm{d}}$ & $<0.01$ \\
\hline $\begin{array}{l}\text { Sterna antillarum } \\
\text { Bridled tern }\end{array}$ & 60 & 2250 & 2.67 & $?$ & $?$ \\
\hline $\begin{array}{l}\text { Sterna anaethetus } \\
\text { Brown noddy }\end{array}$ & 140 & 6000 & 2.33 & $200000^{\mathrm{d}}$ & 0.07 \\
\hline Anous stolidus & 103 & 14000 & 0.74 & $400000^{\mathrm{d}}$ & 0.03 \\
\hline
\end{tabular}

used numbers of breeding pairs, our regional and global estimates should also be taken as minimum values, as the $1 \%$ threshold limits (BirdLife International) take into account all individuals of a species, including nonbreeders. In addition, many seabird biologists believe that a number of these species represent regionally endemic subspecies which, if true, would only enhance the importance of the BVI seabird assemblage.

Introduced species are a major threat to nesting seabirds around the globe as they directly consume adult birds, chicks and eggs or inadvertently destroy nests and vegetation used for nesting (Courchamp et al. 2003). There is no published information regarding the distribution or population sizes of any introduced vertebrate species in the BVI, which includes cats Felis catus, rats Rattus sp., goats Capra hircus and the West Indian mongoose Herpestes auropunctatus, which was introduced as a biological control agent in the 1880's (Nellis \& Everard 1983). The feral goat population on Great Tobago has recently undergone an eradication program, and the frigatebird colony is thought to be expanding with birds now nesting in low vegetation ( $<1 \mathrm{~m}$ high) throughout Man-OWar Bay (N. K. Woodfield pers obs.). Given the important regional status of

The number of brown noddy Anous stolidus pairs was higher in 2005, which probably reflects the increased survey effort. Numbers of this species are approaching the $1 \%$ regional threshold and our data are probably minimum estimates due to nests occurring on high cliff ledges and in crevices, which are difficult to survey.

The number of Audubon's shearwaters is still unknown in the BVI, as we were unable to conduct any night surveys or playbacks at suspected colonies. However, we strongly suspect that the shearwaters are still breeding in the BVI as calling birds have been heard at night off several of the islands during the breeding season (C. Petrovic pers. comm.).

It is worth highlighting that our estimates of the number of breeding pairs must be interpreted as the minimum, as we did not cover all the potential nesting areas on all islands. Several islands have internal salt ponds, which were not surveyed; neither did we cover every island and cay in the archipelago. As we only the BVI breeding seabirds and the major impact that introduced mammals have on seabird populations it would seem obvious that the Government of the BVI has an obligation to assess levels of predator impact and consider implementing eradication programs on some of the more important islands.

The current legislation protecting seabirds in the BVI is the Wild Birds Protection Ordinance 1980, which prohibits the killing, injuring or taking of any wild bird and the damaging or destroying of any wild bird egg or nest. Nevertheless, egg collection for human consumption still persists, and there is little enforcement of the above legislation (Schreiber \& Lee 2000). The Protection Ordinance is open to wide interpretation, but the majority of its weaknesses have been identified within government. The BVI National Parks Trust and the BVI Conservation and Fisheries Department have thus recommended amendments that will offer better protection and allow officials to better enforce the Ordinance. 
Disturbance of seabirds at breeding colonies can cause adults to desert, resulting in chick mortality (Del Viego et al. 2004.) There is no protection against disturbance for seabird colonies in the BVI. Over 650000 people visited the BVI in 2003, of which approximately a third utilised the charter boat industry (BVI Government, Development and Planning Unit 2005), which indicates that disturbance at colonies from recreational boat users and other tourist activity is almost certainly occurring. We suggest that the current legislation be further amended to restrict access and minimise disturbance at the most important colony sites highlighted here.

In summary, the BVI are highly important for breeding seabirds in a global and regional context2 of the colonies seem to be globally significant, whilst a further 8 species have regionally significant populations. Of the remaining breeding species, 3 are most probably present in regionally significant numbers, whilst 1 species (Audubon's shearwater) is still data deficient. Awareness of this importance is not great, and should therefore be promoted throughout the territory and the wider Caribbean in conjunction with a concerted management and monitoring program. The existing fundamental barriers to seabird conservation in the BVI, discussed herein, will need to be addressed to ensure the continued existence of the seabird colonies recorded there.

Acknowledgements. We thank Clive Petrovic, BVI CFD, BVI NPT, and the FCO for their assistance in completing this work. We also thank Jim White, Damon Wheatley, Rondel Smith and the people of Anegada for all their help and Matthew Witt for his invaluable input. Additionally we thank 3 anonymous referees, whose comments helped to improve the manuscript. This work was funded by the U.K. Darwin Initiative (Project Ref No. 162/12/023).

Editorial responsibility: Rory Wilson, Swansea, UK

\section{LITERATURE CITED}

BirdLife International (2003) Birdlife's online World Bird Database: the site for bird conservation. Version 2.0. BirdLife International, Cambridge. Available at: www.birdlife.org

BVI Government, Development and Planning Unit (2005) Tourism summary, Development Planning Unit, Government, British Virgin Islands. Available at: http:// dpu.gov.vg/Indicators/tourism/TourismSummary.html

Conservation International (2005) Caribbean Islands. Available at: www.biodiversityhotspots.org/xp/Hotspots/ caribbean/biodiversity.xml

Courchamp F, Chapuis JL, Pascal M (2003) Mammal invaders on islands: impact, control and control impact. Biol Rev 78:347-383

del Hoyo J, Elliot A, Sargatal J (1992) Handbook of the birds of the world. Lynx Edicions, Barcelona

del Hoyo J, Elliot A, Sargatal J (1994) Handbook of the birds of the world. Lynx Edicions, Barcelona

Del Viego A, Vega X, Gonzalez M, Sanchez J (2004) Disturbance, human predation and reproductive success of seabirds in tropical coastal ecosystems of Sinaloa state, Mexico. Bird Conserv Int 14:191-202

Lee DS, Walso-McGehee M (2000) Population estimates, conservation concerns, and management of tropicbirds in the Western Atlantic. Caribb J Sci 36:267-279

Myers N, Mittermeier RA, Mittermeier CG, da Fonseca GAB, Kent J (2000) Biodiversity hotspots for conservation priorities. Nature 403:853-858

Nellis DW, Everard COR (1983) The biology of the mongoose in the Caribbean. In: Wagenaar Hummelinck P, van der Steen LJ (eds) Studies on the fauna of Curaçao and other Caribbean Islands, No. 195. Foundation for Scientific Research in Surinam and the Netherlands Antilles, Utrecht

Raffaele HA (1989) Birds of Puerto Rico and the Virgin Islands. Princeton University Press, Princeton, NJ

Rose PM, Scott DA (1997) Waterfowl population estimates. 2nd edn. Wetlands International, Wageningen

Saliva JE (2000) Conservation priorities for roseate terns in the West Indies. In: Schreiber EA, Lee DS (eds) Status and conservation of West Indian seabirds. Society of Caribbean Ornithology, Spec. Publ. 1, p 87-95

Schreiber EA, Lee DS (2000) Status and conservation of West Indian seabirds, Society of Caribbean Ornithology, Spec. Publ. 1

Submitted: December 21, 2005; Accepted: March 28, 2006 Proofs received from author(s): May 1, 2006 